\title{
The Contribution of Government Expenditure on Economic Growth of Nigeria Disaggregated Approach \\ Eugene Iheanacho*
}

Department of Economics, Abia State University Uturu, Nigeria

\begin{abstract}
This study examines the long and short run relationship between public expenditure and economic growth in Nigeria over the period of 1986-2014, using Johansen cointegration and error correction approach. Two components of public sector expenditure and gross capital formation ratio are derived from Cobb Douglas production function. The result shows recurrent expenditure is the major driver of economic growth in Nigeria. Controlling for the influence of non-oil revenue, this study shows a negative and significant long run relationship between economic growth (rgdpc) and recurrent expenditure coexists with a positive short run relationship, highlighting the dual effects of recurrent expenditure on economic growth in Nigeria. For the capital expenditure, this study documents negative and significant long run effect of capital expenditure on economic growth in Nigeria. The variance decomposition confirms the collective contribution of public expenditure on economic growth. The finding of this study have some policy implications for policyholders because it could be guide on effective utilization of public funds on rightful projects rather than spending it on enormous projects that will not translate into meaningful growth of the economy.
\end{abstract}

Keywords: Recurrent expenditure; Capital expenditure; Gross capital formation; Johansen cointegration; Economic growth; Government expenditure

\section{Introduction}

For decades the relationship between public sector expenditure and economic growth has continued to occupy series of debate among researchers and policy makers. The common consensus among the researchers is that public sector expenditure has been identified as an important instrument which the government uses to influence the performance of the economy [1-3]. The channel through which public authorities satisfy the collective want of the people can be classified under public sector expenditure. Salawu observed that public expenditure is the expenses incurred by the government for the maintenance of itself, the economy and the society at large. Public expenditure is an important mechanism which the government uses to pilot significant effects on the general growth of the economy. Anyanwu [4] observed that public expenditure is simply government spending from revenue derived from taxes and other sources. Again, the study articulated that public expenditure is centered on expenses contracted on government own maintenance for the growth and stability of the general economy. Another study by Anyanwu [5] noted that public expenditure is that part of fiscal tools that embraces and puts to use judiciously, all revenue generated from all sources, for the growth and installed system in the economy.

On decomposed level, Ankrani is of the opinion that government spending on collective needs and wants of the country in different areas including pension, infrastructure, capital investment, roads etc. are categorically classified under public sector expenditure. Jhingan [6] conclusively added that public expenditure is "the beginning and end of the collection of revenues by the government".

In line with the aforementioned, there is a direct relationship between the amount of public sector expenditure and economic growth. Therefore, the policy makers place more emphasis on the roles of public sector expenditure as an instrument which the government can apply to restore some economic problems such as reduction in inequality, inflation, fall in exchange rate, unemployment, dwindling oil price and the desire to restore the economy on the part of full employment, price stability, balance of payment equilibrium and above all, increase in economic growth. No wonder Mankiw, David, and David [7] earlier reviewed that economic growth is the increase in the inflation-adjusted market value of goods and services produced by economy overtime. Ideally, economic growth brings about a better standard of living of the people and this most at times is brought about by improvement in availability of infrastructure, access to food, health, housing, education, good roads etc. These improvements are very important in stimulating economic activities as well as addressing the nation's human capital development.

Another point of interest among scholars in Nigeria economy is that total government expenditure in terms of capital and recurrent expenditures have continued to rise over the last three decades [8]. Notable studies in the likes of Abu, Abdullahi and Omoke all stressed that expenditure on defense, internal security, education, health, agriculture, construction transport and communication are rising overtime.

Judging from the above viewpoints, the various components of capital and recurrent expenditure have risen between the decades of 1981 and 2010. It has been a great debate among researchers in economic literature on the impact and contribution of this multiple increase in our economy [9] emphasized that recurrent expenditure during the last decade under review (2010) had accounted for over 50\% of total expenditure, while the share of capital expenditure was relatively below $50 \%$ of total public sector expenditure. It must also be noted that the public sector capital expenditure, theoretically, is the aspect of public sector expenditure expected to drive economic growth. Out of the various categories in public sector capital expenditure, in the light of the foregoing, it could be deduced that the current state of Nigeria economy could be partly linked to the nature of public sector expenditure. Intuitively, for a developing nation capital expenditure particularly

*Corresponding author: Eugene Iheanacho, Department of Economics, Abia State University Uturu, Nigeria, Tel:+234 811968 4648; E-mail: eugene.iheanacho2016@yahoo.com

Received August 02, 2016; Accepted August 23, 2016; Published August 25 2016

Citation: Iheanacho E (2016) The Contribution of Government Expenditure on Economic Growth of Nigeria Disaggregated Approach. Int J Econ Manag Sci 5 369. doi: 10.4172/2162-6359.1000369

Copyright: (C) 2016 Iheanacho E. This is an open-access article distributed unde the terms of the Creative Commons Attribution License, which permits unrestricted use, distribution, and reproduction in any medium, provided the original author and source are credited. 
in capital projects or infrastructural development ought to constitute significant proportion of her total public sector expenditure to lay the foundation for economic growth and sustainable development, but this has not been the case in Nigeria. However, we are careful not to jump to the conclusion that the preponderance of recurrent expenditure over capital expenditure has -adversely affected the nation's economy. This is purely on the desired results in the economy to force an increasing intervention on the part of the state. This did not lead to a rapid growth in the public sector and public sector expenditure but, also fed various analytical hypotheses concerning public expenditure [10].

A question therefore, poses itself: "Is the increasing public sector expenditure influencing the rate of economic growth in Nigeria?" Specifically, Jhingan observed that some of the reasons adduced for the increase in government expenditure overtime are; inflation, public debt, tax revenue and population.

Researching further, it is a common belief that the government plays a significant role in the development of a country and the public sector expenditure is an important instrument for the government to control the economy. Also, economists have noted its effects in promoting economic growth. Meanwhile, the general view is that public sector expenditure either recurrent or capital expenditure notably on social and economic infrastructure can be growth enhancing. Jhingan stated that public sector expenditure, by increasing social welfare, helps in reducing inequalities of income and wealth and as well can be used to create trade as well as to correct externalities and regional disparities if employed judiciously, thereby fastening economic growth.

From this point that Omoke conclusively put that an increase in government expenditure will yield a positive increase in the growth of the economy by increasing the national income especially, when it is injected in development programs. For example, government expenditure on social and community services such as health and education are capable of raising the productivity of labour and increase the growth of national output. Also, an increase in infrastructural equipment and rise in salaries will motivate the lecturers and teachers to dedicate more time in equipping the students with more skills and knowledge. Similarly, Abu and Abdullah observed that the public sector expenditure on infrastructure such as roads, communication, power etc. reduces production costs, increase private sector investment and profitability of firms and fosters economic growth.

In Nigeria today, the public sector is predominant. The reason appears to lie in what the government perceived as its social responsibility or share of commitment in the growth and development process. Its largeness has been stimulated by the urge to adopt shock adjustment to economic growth for quicker realization of national aspiration. This has led to the overwhelming consistent increase in the public sector expenditure in Nigeria [11]. Specifically, the public sector expenditure in Nigeria has continued to raise for over three decades, due to the increased demand for public (utilities) goods like roads, communication, power, education and health [12]. However, it has been argued by scholars if the rising state of public sector expenditure in Nigeria has gainfully contributed to economic growth in Nigeria. Okoro pointed that increase in per capita which are a symbol of economic growth that leads to development and reduction in poverty. However, the study alarmed that many Nigerians have continued to wallow in abject poverty, while more than $50 \%$ live on less than US $\$ 1$ per day [13]. Moreover, macroeconomic indicators like balance of payments, import obligations, inflation rate, exchange rate, and national savings reveal that Nigeria has not fared well in the last three decades.
Furthermore, public sector has incurred expenses in areas such as physical infrastructure, health, education, economic services, defence and general administration. Economic theory predicts that increases in productive public spending in areas like physical infrastructure, health and education leads to increases in economic growth of a country. Some governments have tried to promote public spending due to an understanding that large public sector expenditure is a source of economic growth and development, especially, in a country where public sector is predominant like Nigeria. Therefore, understanding the relationship between public expenditure and economic growth could have a significant impact on the formulation and implementation of major macroeconomic policies. It could also guide the formulation of major economic policies required urgent funding and attention.

Controlling for the influence of non-oil revenue, this study seeks to uncover the long run and short run relationship between public sector and economic growth in Nigeria using Johansen cointegration approach. By examining the effect of public expenditure on economic growth, this study contributes to a number of studies that have explored public sector contribution on economic growth [14].

The remainder of this study is structured as follows: Section 2 details the literature. Section 3 contains details of the data and methodology employed the study. Section 4 contains the presentation of results. Section 5 offers an analysis of the results presented in the previous section and Section 6 concludes this paper.

\section{Literature Review}

\section{Theoretical review}

In the past, economic literature has amongst other things, concerned itself with the research and study of the relationships between public sector and economic growth. The major consensus is public sector expenditure impacts positively on economic growth. Notable theories are Keynes [15], Wagner [16], Peacock and Wiseman [17]. Keynes, in his hypothesis draws a link between public expenditure and economic growth and concludes that causality runs from public expenditure to income, implying that public sector expenditure is an exogenous factor and a public instrument for increasing national income. Furthermore, holds that increase in government expenditure leads to higher economic growth. Wagner, Peacock and Wiseman and many other economists have formulated different theories on public expenditure and economic growth. Wagner positioned public sector expenditure as a behavioural variable that positively dictates if an economy is growing. However, the neo classical growth model developed by Solow [18] opined that the fiscal policy does not have any effect on the growth of national output. Another study by Solow [19] further argued that invention through fiscal policy helps to improve failure that might arise from the inefficiencies of the market. Similarly, Dar and Amir [20] summarized that in the endogenous growth models, fiscal policy is very crucial in predicting future economic growth. Nevertheless, Barro [21], Barro and Sali-i-Martins [22] and Roux [23] all noted that the expansion of government expenditure contributes positively to economic growth. However, Chude and Chude expressed that some researchers and policy makers do not support the claim that increasing government expenditure promotes economic growth. Instead, they assert that higher public expenditure may slow down overall performance of the economy. For instance, in an attempt to finance rising expenditure, government may increase taxes and/or borrowing. Glomm and Rarikumma [24] articulated that higher income tax discourages individuals from working for long hours or even searching for job. This in turn reduces income and aggregate demand. In the same vein, higher profit tax tends 
to increase production costs and reduce investment expenditure as well as profitability of firms.

Putting public expenditure into perspective, Pearce [25] noted that Public expenditure is associated with the public sector. The study emphasized that the phrase "public sector" could be referred to as that part of the economy, which is publicly owned as opposed to privately owned. It thus includes all government departments and agencies and all public corporations such as electricity boards, water boards etc. Here, the public sector is thus defined in terms of ownership. It should not be defined as the sector only, which produces only public goods although, typically, public goods are provided via the public sector. Afolabi [26] viewed the public sector the same as government sector consisting mainly of the government and government owned enterprises whether local, state or federal. In his view, Afolabi stated that the public sector is an economic agent acting on behalf of everybody generally with all its economic resources commonly owned and all its activities presumably carried out on behalf of, and for the benefit of everybody.

Meanwhile, the public sector is that portion of the society controlled by national or federal, state and local governments. The public sector encompasses defence, homeland security, public protection, firefighting, urban planning, taxation and various social programs. Nweke [27] pointed that Public ownership in key sectors of the economy were viewed as a more effective way to achieve economic growth and development since it was believed that the private sector in developing countries lacked the means (financial and entrepreneurial skill) to undertake the task of development. Anyanwu highlighted that public expenditure is usually categorized into recurrent and capital expenditure. In his view, Anyanwu noted that these are further broken down into their various compositions. For example; recurrent water supply etc. these are basis for an industrial take off which are necessary for economic growth and development.

\section{Empirical literature}

Recent evidence documents that, the size, structure and growth of public sector expenditure have increased tremendously and become increasingly complex. Olulu et al. observed that not only has recent political developments engendered expenditure growth, the challenge of raising additional and identifying alternative sources of revenue to meet the ever increasing needs of governance have made it more imperative to take a more focused look at government activities, especially its expenditures. Researchers have attempted to examine the impact of public expenditure on economic growth in different countries and periods. Alexander [28] applied OLS method for sample of 13 Organization for Economic Cooperation and Development (OECD) countries panel during the period ranging from 1959 to 1984. The results show, among others, that growth of government spending has significant negative impact on economic growth Foster and Skinner evaluated the relationship between government expenditure and economic growth for a sample of wealthy countries for 1970-95 periods, using various econometric approaches. They found a positive relationship between public sector expenditure and economic growth Devarajan et al. studied the effects of different expenditure component on growth. The study covered 43 countries for periods of 1970 to 1990. The study shows that recurrent expenditure has positive impact on growth, while capital expenditure exerts negative impact on growth. But when a subsample of developed countries were considered the result was reversed indicating that, the earlier result might be as a result of corruption and inefficiency in the use of public funds in the developing countries. Abu-Bader and Abu-Qarn employed multivariate co-integration and variance decomposition approach to examine the causal relationship between government expenditures and economic growth for Egypt, Israel, and Syria for the period 1970 to 2000. In the bivariate framework, the authors observed a bidirectional (feedback) and long run negative relationships between government spending and economic growth. Moreover, the causality test within the tri-variant framework (that include share of government civilian expenditures in GDP, military burden, and economic growth) illustrated that military burden has a negative impact on economic growth in all the countries. Furthermore, civilian government expenditures have positive effect on economic growth for both Israel and Egypt. Josaphat and Oliver [29] investigated the impact of government spending on economic growth in Tanzania (1965-1996) using time series data for 32 years. They formulated a simple growth accounting model, adapting Ram [30] model in which total government expenditure is disaggregated into expenditure on (physical) investment, consumption spending and human capital investment. It was found that increased productive expenditure (physical investment) have a negative impact on growth and consumption expenditure relates positively to growth, and which in particular appears to be associated with increased private consumption. The results revealed that expenditure on human capital investment was insignificant in their regression and confirm the view that public investment in Tanzania has not been productive, as at when the research was conducted.

Liu et al. [31] examined the causal relationship between GDP and public expenditure for United States of America using data from the period 1947-2002. The causality results revealed that total government expenditure causes growth of GDP. On the other hand, growth of GDP does not cause expansion of government expenditure. Moreover, the estimation results indicated that public expenditure raises the US economicgrowth. The authors concluded that, judging from the causality test Keynesian hypothesis exerts more influence than the Wagner's law in US. In Nigeria, many researchers and policy makers have attempted to examine the relationship between the two macroeconomic, variables. Fajingbesi and Odusola [32] empirically investigated the relationship between government expenditure and economic growth in Nigeria over the period 1970 to 1995 . The econometric results indicated that real government capital expenditure has a significant positive influence on real output. However, the results showed that real government recurrent expenditure affects economic growth only by little.

Also, study by Ogiogio [33] revealed a long-term relationship between government expenditure and economic growth over the period 1970 to 1990 in Nigeria. Moreover, the author's findings showed that recurrent expenditure exerts more influence than capital expenditure on growth. Ighodaro and Okiakhi [34] used time series data for the period 1961 to 2007 and applied Co-integration Test and Granger Causality test to examine the relationship between government expenditure and economic growth in Nigeria. The results revealed negative impact of government expenditure on economic growth in Nigeria. Okoro investigated the impact of public expenditure on economic growth in Nigeria (1981-2011). The study concluded that Government capital spending in industries and agriculture "if properly managed" will raise the nation's production capacity and employment, which in turn will increase economic growth in Nigeria. The study advised that Government should increase its expenditure on rural roads and electricity as this will accelerate the productive sectors as well as raise the standard of living of poor citizens in Nigeria. Chude and Chude while studying the impact of government expenditure on economic growth in Nigeria (1977-2012) found that total government 
expenditure on education has significant effect on Gross Domestic Product (GDP). The study suggested that Government should direct its expenditure towards the productive sectors like education as it would reduce the cost of doing business as well as raise the standard living of poor ones in the country. Again, Chude and Chude concluded that Government should ensure that capital expenditure and recurrent expenditure are properly managed in a manner that it will raise the nation's production capacity. Ebiringa and Charlse-Anyaogu examined the impact of sectorial expenditure on the economic growth of Nigeria from 1977 to 2011. Their analysis viewed that government expenditure should spend more on health sector, education, Telecommunication and security since they are significant and have positive impact on the economic growth of the nation. Barro observed that empirical evidence on the relationship between government spending and economic growth is diverse, mostly on cross section studies that include a sample of both advanced and developing countries. The main conclusion in most of these studies is that government consumption spending has a negative impact on growth.

\section{Data and Model Specification}

\section{Data}

This study uses annual data covering the period from 1986 to 2014. Two widely used component of public sector expenditure are employed: recurrent expenditure and capital expenditure. Non-oil revenue is included in the study to control for the influence of other component of the economic growth or determinant. These factors have been identifying among the most significant determinants and proxies for public sector expenditure. Table 1 provides additional information on all the variables.

\section{Model specification}

In spirit with Rivera-batiz [35], and N'Zue [36], the author considers a Cobb-Douglas production function which is specified as follows;

$$
\mathrm{Y}=\mathrm{AL}{ }^{\alpha} \mathrm{K}^{\beta}
$$

Where $\mathrm{Y}$ is economic growth measured by real GDP per capita, $\mathrm{K}$ is the capital stock measured by gross fixed capital formation and $\mathrm{A}$ is the total factor productivity, a determines the share of output that goes to capital and the share that goes to labour. Assuming the author augment the neo classical cobb-Douglas production by incorporating recurrent, capital expenditure and non-oil revenue as: $\mathrm{A}=\mathrm{f}$ (recurrent expenditure, capital expenditure and non-oil revenue), whereas $\mathrm{L}$ cancel out on both right and let of the equation to arrive at rgdpc and gcfr respectively. Therefore, the Neo classical Cobb-Douglas production could be rewritten to give the model as thus;

$$
\operatorname{rgdpc}=\mathrm{f} \text { (gcfr, rex, ces, noilr) }
$$

The above equation can be written in econometric model and in their respective natural $\log$ form as thus;

$$
\operatorname{lng} \mathrm{dpc}=\alpha_{0}+\beta_{1} \operatorname{lngcfr}+\beta_{2} \ln r e x+\beta_{3} \operatorname{lnces}+\beta_{4} \operatorname{lnnoilr}+\varepsilon_{\mathrm{t}}
$$

Where lnrgdpc is log of real gdp per capita, lnrex is log of recurrent expenditure, lnces is log of capital expenditure, lnnoilr is the log of nonoil revenue, $\varepsilon_{\mathrm{t}}$ is the error term and $\alpha_{0}$ is the intercept.

\section{Empirical Methodology}

\section{Unit root test}

In time series analysis, before running the cointegration test the variables must be tested for stationarity. For this purpose, we use the conventional ADF tests, the Phillips-Perron test following Phillips and Perron. Therefore, before applying this test, we determine the order of integration of all variables using unit root tests by testing for null hypothesis $\mathrm{H}: \beta=0$ (i.e $\beta$ has a unit root), and the alternative hypothesis is $\mathrm{H}_{1}: \beta<0$. All the variables should be integrated at first order difference I(1) so as to avoid spurious result.

\section{Cointegration}

This study adopts a dynamic vector autoregressive regression (VAR) which explores cointegration. The essence is to capture the causal dynamics relationship between government expenditure and economic growth, and at the same time to observe the long run and short dynamics. For instance, given a VAR with possible long run cointegration amongst a set of variables.

Therefore, we start with the Johansen co-integration equation which starts with the vector auto regression (VAR) of order $\mathrm{p}$ is given by:

$$
\mathrm{y}_{\mathrm{t}}=\mu+\mathrm{A}_{1} \mathrm{y}_{\mathrm{t}-1+\cdots} \ldots \mathrm{A}_{\mathrm{p}} \mathrm{y}_{\mathrm{t}-\mathrm{p}}+\varepsilon_{\mathrm{t}}
$$

Where $y_{\mathrm{t}}$ is a $(\mathrm{nx} 1)$ vector of variables under considertion in $\log$ form that are integrated at order one-commonly denoted $1(1), n=5 \mathrm{~A}$ are the parameters to be estimated, $\varepsilon_{\mathrm{t}}$ are the random errors. This (VAR) can be re-written as;

$$
\Delta \mathrm{y}_{\mathrm{t}}=\mu+\prod \mathrm{y}_{\mathrm{t}-1}+\sum_{\mathrm{i}=1}^{\mathrm{p}=1} \Gamma_{\mathrm{i}} \Delta \mathrm{y}_{\mathrm{t}-\mathrm{i}}+\varepsilon_{\mathrm{t}}
$$

Where,

$$
\begin{aligned}
& \Pi=\sum_{i=1}^{p} A_{i}-1 \\
& \Gamma_{i}=-\sum_{j=i+1}^{p} A_{j}
\end{aligned}
$$

\begin{tabular}{|c|l|c|c|}
\hline Variable & \multicolumn{1}{|c|}{ Definition } & Unit & \multicolumn{1}{|c|}{ Sources } \\
\hline RGDPC & $\begin{array}{l}\text { Represents the Real Gross Domestic Product per capita. It is derived by dividing the real GDP by } \\
\text { total population. It captures economic growth of Nigeria 'from 1986-2014. This is consistent with the } \\
\text { study by Okoro (2013). }\end{array}$ & InRGDP & CBN Statistical Bulletin (2014) \\
\hline GFCFR & $\begin{array}{l}\text { Represents the rate of domestic investment. It is derived by dividing gross fixed capital formation by } \\
\text { total population. Its captures the rate of domestic investment which is consistent with Ajide (2014). }\end{array}$ & InGFCFR & CBN Statistical Bulletin (2014) \\
\hline NOILR & It represents all the income from dgp other than oil sector & InNOILR & CBN Statistical Bulletin (2014) \\
\hline CEX & $\begin{array}{l}\text { Represents public sector capital expenditure which includes capital expenditure on administration. } \\
\text { Economic services, social and community services, transfers etc. In consistent with Abu-Bader and } \\
\text { Abu-Qarn (2003) and Josaphat and Oliver (2000). }\end{array}$ & InCEX \\
\hline REX & $\begin{array}{l}\text { Represents public sector recurrent expenditure on administration. economic services, social.' and } \\
\text { community services, transfers etc. In consistent with Abu-Bader and Abu-Qarn (2003) and Josaphat } \\
\text { and Oliver (2000). }\end{array}$ & InREX & CBN Statistical Bulletin (2014) \\
\hline
\end{tabular}

Table 1: List of variables. Source: Author's design. 
If the coefficient matrix $\Pi$ has reduced $\operatorname{rank} r<n$, then there exist $n$ $\times r$ matrices of $\alpha$ and $\beta$ each with rank $r$ such that

$$
\Pi=\alpha \beta^{\prime}
$$

Where $r$ is the number of co-integrating relationship, the element is $\alpha$ is known as the adjustment parameters in the vector error correction model and each column of $\beta$ is a cointegrating vector. It can be shown that, for a given $r$, the maximum likelihood estimator of $\beta$ define the combination of $y_{t-1}$ that yield the $r$ largest canonical correlations of $\Delta \mathrm{y}$ with $\mathrm{y}_{\mathrm{t}-1}$ after correcting for lagged differences and deterministic variables when present. The two different likelihood ratio test of significance of these canonical correlations are the trace test and maximum eigenvalue test, shown in equation 5 and 6 respectively below

$$
\begin{aligned}
& \lambda_{\text {trace }}(\mathrm{r})=-\mathrm{T} \sum_{\mathrm{i}=\mathrm{r}+1}^{\mathrm{n}} \ln \left(1-\hat{\lambda}_{\mathrm{l}}\right) \\
& \lambda_{\text {max }}(\mathrm{r}, \mathrm{r}+1)=-\mathrm{T} \ln \left(1-\hat{\lambda}_{\mathrm{r}+1}\right)
\end{aligned}
$$

Here, $\mathrm{T}$ is the sample size and $\hat{\lambda}_{i}$ is the $\mathrm{i}^{\mathrm{th}}$ ordered eigenvalue from the $\pi$ matrix in equation 3 or largest canonical correlation. The trace tests the null hypothesis that the number of $\mathrm{r}$ co-integrating vector against the alternative hypothesis of $n$ co-integrating vector where $n$ the number of endogenous variables is. The maximum eigenvalue tests the null hypothesis that there are $r$ cointegrating vectors against an alternative of $\mathrm{r}+1$.

After testing for cointegration among the variables, the long run coefficients of the variables are the estimated. This study uses Akaike information criteria for selected the optimal lag length. The existence of cointegration between the variables implies that causality exists in at least one direction. The short run equilibrium relationship is tested using vector error correction model (VECM). VECM is restricted VAR that has cointegration restriction built into the specification. The VECM analysis in this study is based on equation 2 and it involves five cointegrating vector as thus:

$$
\begin{aligned}
\Delta \operatorname{lngdp}_{\mathrm{t}}= & \alpha_{0}+\sum_{\mathrm{i}=1}^{\mathrm{n}} \beta_{1 \mathrm{i}} \Delta \operatorname{lngrgdp}_{\mathrm{t}-1}+\sum_{\mathrm{i}=0}^{\mathrm{n}} \beta_{2 \mathrm{i}} \Delta \operatorname{lngcfr}_{\mathrm{t}_{\mathrm{t}-1}}+\sum_{\mathrm{i}=0}^{\mathrm{n}} \beta_{3 \mathrm{i}} \Delta \operatorname{lnrex}_{2_{\mathrm{t}-1}} \\
& +\sum_{\mathrm{i}=0}^{\mathrm{n}} \beta_{3 \mathrm{i}} \Delta \operatorname{lnces}_{2_{\mathrm{t}-1}}+\sum_{\mathrm{i}=0}^{\mathrm{n}} \beta_{3 \mathrm{i}} \Delta \operatorname{lnnoilr}_{\mathrm{t}_{\mathrm{t}-1}}+\lambda_{\mathrm{l}} \mathrm{ecm}_{\mathrm{t}-1}+\mu_{\mathrm{t}}
\end{aligned}
$$

$\mathrm{ecm}_{\mathrm{t}-1}$ is the error correction term obtained from the cointegration model. The error coefficients $\left(\lambda_{1}\right)$ indicate the rate at which the cointegration model corrects its previous period's disequilibrium or speed of adjustment to restore the long run equilibrium relationship. A negative and significant $\mathrm{ecm}_{\mathrm{t}-1}$ coefficient implies that any short run movement between the dependant and explanatory variables will converge back to the long run relationship.

Diagnostic test: To ensure the goodness of fit of the model, diagnostic tests are conducted. Diagnostic tests examine the model for serial correlation, and heteroscedasticity.

\section{Emperical Results}

\section{Descriptive statistics and graphical analysis}

Table 2 above provides the summary statistics, namely, sample means, maximums, minimums, medians, standard deviations, skewness, kurtosis and the Jarque-Bera tests with their p-values. Three indictors of government expenditures: recurrent expenditure ( REX), capital expenditure ( CES), aggregate government expenditure, gross capital formation ratio (GCFR) and one control variable non-oil price (NOILR) over the period 1986-2014. Whilst it is clear that all the statistics show the characteristics common with most time series, for instance normality in the form of playykurtic, there are a number of noticeable differences, between the variables. Firstly, economic growth (lnRGDPC) has the largest unconditional average of 12.37 while recurrent expenditure (lnREX) has the least unconditional average of 5.201. This depicts recurrent expenditure has the lowest minimum and maximum value (7.0499 and 1.8519) respectively, while economic growth maintained the highest maximum and minimum value with 12.855 and 12.05 respectively.

The standard deviation shows the level of volatility in the variables. It displays the rate at which each variable deviates from the mean value. From the Table 2 above, public sector recurrent expenditure (non-oil revenue-NOILR) is the most volatile at 2.042 while the rate of $\operatorname{lnGDPC}$ is the less volatile 0.274 (approximately). The level of volatility in other variables are RGDPC $1.68 \%$ (approximately), lnREX 1.88 (approximately),lnCEX 1.85, lnGCFR 1.93 and $\ln$ APEX 1.841.

The skewness measures the asymmetric nature of the data; Skewness is a measure of the asymmetry of the probability distribution of a real-valued random variable about its mean. A normal distribution is symmetrical at point 0 . If the value is greater than zero $(>0)$ it's positively skewed, but if less than zero $(<0)$ it is negatively skewed [37]. Economic growth (lnRGDPC) and rate of domestic investment (lnGFCFR) are positively skewed with the values 0.6412 and 0.122 respectively while public sector expenditure (lnAPEX), recurrent expenditure (lnREX), capital expenditure (lnCEX) and non-oil revenue (NOILR) are negatively skewed with values $-0.4763,-0.3491,-0.7544$ and -0.3908 respectively.

Kurtosis measures the sharpness of the peak of a normal distribution curve. It is a measure of "tailedness" of the probability distribution of a real-valued random variable [38]. If the value is approximately equal to 3 , it is said to be mesokurtic distribution implying that it is normally distribution. If approximately greater than 3 , it is leptokurtic distribution which has tails that asymptotically approach zero slowly and has more outliers than the normal distribution. While if approximately, less than 3 it is platykurtic which means that the distribution produces fewer and less outliers than the normal distribution. Therefore, all the series show evidence of playtykurtic with values less than 3 .

The Jarque-Bera is a test for normality of the distribution where the null hypothesis is that the distribution of the sample is a normal one. If the probability value of the Jarque-Bera test is significant, then the null hypothesis is rejected and the alternative is accepted which says that the sample is not normally distributed. If each variable is statistically significant (indicated by a zero probability), then the series are not normally distributed. Therefore the farther the probability statistic of a variable is to zero, the lower the value of its Jarque-Bera statistic and the more normally distributed it is and vice versa. From the results above,

\begin{tabular}{|c|c|c|c|c|c|c|}
\hline & LRGDPC & LREX & LCES & LGCFR & LAPEX & LNOILR \\
\hline Mean & 12.37063 & 5.797012 & 5.201698 & 8.126699 & 6.297391 & 5.354993 \\
\hline Median & 12.19823 & 6.134699 & 5.733392 & 7.925879 & 6.854027 & 5.750933 \\
\hline Maximum & 12.85585 & 8.213127 & 7.049946 & 11.31948 & 8.553587 & 8.09411 \\
\hline Minimum & 12.05759 & 2.040818 & 1.851992 & 4.943024 & 2.786473 & 1.501519 \\
\hline Std. Dev. & 0.273519 & 1.885549 & 1.640854 & 1.936291 & 1.810001 & 2.042564 \\
\hline Skewness & 0.614375 & -0.349177 & -0.754449 & 0.122129 & -0.476388 & -0.390855 \\
\hline Kurtosis & 1.658278 & 1.872057 & 2.254201 & 2.066138 & 1.987984 & 1.882928 \\
\hline Jarque-Bera & 3.999634 & 2.12661 & 3.423195 & 1.125876 & 2.334451 & 2.246194 \\
\hline Probability & 0.13536 & 0.345313 & 0.180577 & 0.569533 & 0.311229 & 0.325271 \\
\hline
\end{tabular}

Table 2: summary of descriptive statistic. Source: computed using EViews 9. 
in Table 2 the Jarque-Bera tests show that the null hypothesis is strongly accepted for all the distribution. Hence, the variables can be described to be normally distributed.

\section{Unit root test}

All that data are transformed into the natural log form. To determine the order of integration of the variables, the ADF (augmented DickeyFuller) test complemented with the PP (Philips-Perron) test in which the null hypothesis is $\mathrm{H}_{0}=\beta=0$ (i.e $\beta$ has a unit root), and the alternative hypothesis is $\mathrm{H}_{1}: \beta<0$ are implemented. The results for both the level and differenced variables are presented in Table 3

The stationarity tests were performed first in levels and then in first difference to establish the presence of unit roots and the order of integration in all the variables. The results of the ADF and PP stationarity tests for each variable show that both tests fail to reject the presence of unit root for lnRGDPC, lnREX, lnCES, lnGCFR, lnAPEX and NOILR data series in level, indicating that these variables are nonstationary in levels. The first difference results show that these variables are stationary at $1 \%$ significance level (integrated of order one $1(1)$ ). As mentioned in the preceding sections, a linear combination of I (1) series could be I ( 0$)$ if the series are cointegrated. We thus proceed to test for cointegration of the time series.

\section{Result of cointegrtion test: long-run estimate}

The result of the cointegration test, based on the Johanson cointegration approach is presented in Table 4 . The author established lag 2 using akaike criterion (see appendix 1). Cointegration is tested on the long run relationship between the dependent variable (lnRGDPC), and independent variables; lnREX, lnCES, lnGCFR while controlling NOILR. The table indicates that tests fail to accept the null hypothesis of no cointegration at $5 \%$ level of significance. Both the trace and Maximum Eigenvalue suggest the presence of 1 cointegrating vector. The Johanson cointegration test shows this by comparing the statistic values with the critical value, a result is chosen at the value where the statistic is greater than the corresponding critical value. In this study, it is clear that there is at most 1 cointegrating equation in the model with both trace and maximum eigenvalue values suggest $5 \%$ significance level. This implies that an equilibrium relationship exists among the cointegrating variables (lnRGDPC), lnREX, lnCES, and lnGCFR In addition, no matter the fluctuation in the short run; these variables have the tendency to return to this equilibrium path in the long run.

In order to identify the true cointegrating vectors, the normalised (lnRGDPC) was estimated for the model. The result in equation 11 indicates that there is a significant negative long run relationship between public sector expenditure an economic growth. In the same vein, the equation reveals that there is a significant negative long-run relationship between rate of investment and economic growth in Nigeria. This is an indication that some of the variables studied comove. This

\begin{tabular}{|c|c|c|c|c|}
\hline \multirow{2}{*}{ Variables } & \multicolumn{2}{|c|}{ In level I(0) } & \multicolumn{2}{|c|}{ First difference I(1) } \\
\hline & ADF & PP & ADF & PP \\
\hline InRGDPC & 0.5948 & 0.5389 & $-5.2807^{* * *}$ & $-5.2585^{* * *}$ \\
\hline InGCFR & -0.4742 & -0.2321 & $-5.6798^{\star * *}$ & $-8.6795^{* * *}$ \\
\hline InOILR & -1.8677 & -2.253 & $-7.0746^{\star \star \star}$ & $-8.1002^{* * *}$ \\
\hline InREX & -2.2041 & -2.6219 & $-7.551^{* * *}$ & $-7.6306^{* * *}$ \\
\hline InCES & -1.9222 & -2.0757 & $-5.6427^{* \star *}$ & $-5.6433^{* *}$ \\
\hline InAEX & -2.595 & -2.455 & $-3.517^{\star *}$ & $-7.4277^{* * *}$ \\
\hline
\end{tabular}

Table 3: unit root test. Note: all the variables are in the natural log form. ${ }^{* *}$ level of significance at $5 \%$, ${ }^{* * *}$ level of significant at $1 \%$. findings are suggesting that an increase in public sector expenditures negatively on economic growth. From the findings of this study, a $1 \%$ increase in recurrent and capital expenditure decreases economic growth by $0.52 \%$ and $0.64 \%$.This result is favour of the classical view of the classical economist that implies high government expenditure are source of economic instabilities as stated by David Ricardo. This is also in consistence with the finding of Ram, and Alexander that increased productive expenditure (physical investment) has a negative impact on growth and consumption. However, this study is in contrast with finding of Fajingbesi and Odusola.

Also, the findings of this study suggest that $1 \%$ increase in the rate of domestic investment increases economic growth in Nigeria by about $0.7 \%$. This is consistent with the studies by Athukorala [39], Akinlo [40] and Ibrahim [41].

12.0513+0.007886lnGCFR - 0.649613lnCES - 0.527116lnREX+1.2 $71213 \ln N O I L R+\varepsilon_{t}$

Short-run estimate: Table 5 presents the results of the multivariate error correction model with the optimal lag length chosen using Akaike information criteria (AIC). The ECM (-1) coefficient is known as the speed adjustment factor, it shows how fast the system adjust to restore equilibrium. The speed adjustment for $\ln$ GDPC is negative and significant at $1 \%$ level. The coefficient suggests that over $13 \%$ of the short run disequilibrium is corrected in the long run equilibrium, meaning that every shock in the short run result is in a new equilibrium. Hence, economic growth adjusts the disturbances to restore long run equilibrium.

The short run effect of gross capital formation on economic growth is found to be different from the long run effect as reported in Table 5.The coefficient of $\operatorname{lnGCFR}$ and $\operatorname{lnCES}$ are negative and statistically insignificant. Surprising, public expenditure on recurrent expenditure appears to be positive and statistical significant. The coefficient is 0.1019 which shows that $1 \%$ increase in recurrent expenditure in the short run will cause the economic captured by real GDP per capital to increase by $10.19 \%$. Foster and Skinner and Devarajan et al. found a positive relationship between public sector recurrent expenditure and economic growth. On the other side, Alexander shows, among others, that growth of government spending has significant negative impact on economic growth. Controlling for the influence of non-oil revenue InNOILR, the coefficient is found to be negative and statistically significant contrary to the long run position with -0.1189 . This indicates

\begin{tabular}{|c|c|c|c|c|c|}
\hline Ho:no of CE & Trace stat & Eigenvalue & $\begin{array}{c}\text { Critical } \\
\text { value 5\% }\end{array}$ & Max stat & $\begin{array}{c}\text { Critical } \\
\text { value 5\% }\end{array}$ \\
\hline $\mathrm{R}=0$ & 132.407 & 0.9451 & $69.818^{\star *}$ & $75.484^{\star *}$ & 33.876 \\
\hline $\mathrm{r}<1$ & 46.923 & 0.6659 & 47.856 & 26.505 & 27.584 \\
\hline $\mathrm{R}<2$ & 28.418 & .4417 & 29.797 & 15.154 & 14.264 \\
\hline $\mathrm{R}<3$ & 13.263 & 0.3488 & 15.494 & 11.154 & 3.8414 \\
\hline $\mathrm{R}<4$ & 3.8414 & 0.0779 & 3.8414 & 2.10877 & 0.077905 \\
\hline
\end{tabular}

Table 4: Joahanson cointegration test. *Trace test indicates 1 cointegrating equ at the 0.05 level which denotes rejection of the hypothesis at the 0.05 level. ** Max test indicates 1 cointegrating equ at the 0.05 level which denotes rejection of the hypothesis at the 0.05 level.

\begin{tabular}{|c|c|c|c|c|c|c|}
\hline ecm (-1) & $\Delta$ InGCFR & $\Delta$ InCES & $\Delta$ InREX & $\Delta$ InNOILR & LM-stat (2) & Het (2) \\
\hline-0.13232 & -0.0758 & 0.10061 & 0.1019 & -0.1189 & 27.42 & 0.2943 \\
\hline$(-2.454)^{\star}$ & $(1.778)$ & $(1.4822)$ & $(2.005)^{\star}$ & $(-2.5395)^{\star *}$ & $(0.3352)$ & $(0.7197)$ \\
\hline
\end{tabular}

Table 5: Short run error correction estimates. Note t-statistics in ( ). *level of significant at $10 \%$. ${ }^{* *}$ level of significant at $5 \%$, Source: Computation using 4 . 


\begin{tabular}{|c|c|c|c|c|c|c|}
\hline Period & S.E. & LRGDPC & LGCFR & LCES & LREX & LNOILR \\
\hline 1 & 0.047004 & 100.0000 & 0.000000 & 0.000000 & 0.000000 & 0.000000 \\
\hline 2 & 0.06675 & 91.3658 & 5.523861 & 0.007028 & 2.120567 & 0.982748 \\
\hline 3 & 0.073452 & 86.98799 & 5.239935 & 1.602169 & 4.277558 & 1.892347 \\
\hline 4 & 0.088288 & 62.07642 & 6.100357 & 18.14621 & 5.056791 & 8.620226 \\
\hline 5 & 0.109007 & 40.76387 & 4.343065 & 37.55553 & 3.725719 & 13.61181 \\
\hline 6 & 0.134098 & 28.30074 & 3.450967 & 45.42445 & 5.51587 & 17.30797 \\
\hline 7 & 0.161999 & 21.21839 & 3.515998 & 50.82403 & 5.62376 & 18.81782 \\
\hline 8 & 0.191456 & 17.94307 & 3.769715 & 53.00589 & 5.88416 & 19.39717 \\
\hline 9 & 0.218958 & 16.51773 & 3.818249 & 53.91613 & 6.193192 & 19.5547 \\
\hline 10 & 0.245542 & 15.78298 & 3.865193 & 54.42188 & 6.276601 & 19.65335 \\
\hline
\end{tabular}

Table 6: variance decomposition of RGDPC. Source: EViews 9.

that a $1 \%$ fall in non-oil revenue will cause $11 \%$ fall in the economic growth of Nigeria and vice-vasa. Therefore, in the short run recurrent expenditure and non-oil revenue are the major drivers of economic growth in the short-run. Form the diagnostic test result (Table 5); there is no evidence of serial correlation and heteroscedasticity in the vector error correction model.

Forecasting using variance decomposition: Variance decomposition indicates the amount of information each variable contributes to the other variables in the auto regression [42]. It determines how much of the forecast error variance of each of the variables can be explained by exogenous shocks to the other variables. Therefore, Table 6 presents the variance decomposition for economic growth lnNOILR and the 10 years forecast of the contribution of the independent variables. In the first year, economic growth accounts for $100 \%$ of it its changes. In the second year, lnGCFR account for $5.52 \%, \operatorname{lnCES}$ is $0.007 \%, \operatorname{lnREX} 2.12 \%$, lnNOILR is 0.98 of the change in economic growth. From the fourth to the tenth year, this reveals a tremendous increase in capital expenditure indicating a significant impact on the economic growth within the duration of forecast. Other the other side, non-oil revenue has also increase but at a snow rate. The same is applicable to other variables under consideration. Therefore, collective contribution of all dependent variables under consideration indicate that the impact of public expenditure on economic growth is indirect. This is in line relevant studies.

\section{Conclusion and Policy Implication}

Controlling for the possible influence of non-oil revenue, this study examines the long run and short run relationship between public expenditure proxy by (recurrent and capital expenditure) and economic growth in Nigeria using Johansen cointegration approach over 1986-2014. The results show that recurrent expenditure is a major driver of economic growth in Nigeria. A negative and significant long run relationship between economic growth ( $\mathrm{rgdpc}$ ) and recurrent expenditure coexists with a positive short run relationship, highlighting the dual effects of recurrent expenditure on economic growth in Nigeria. In general, the result is in line with documented evidence from relevant studies.

The negative significant long run effect of capital expenditure on economic growth in Nigeria confirms inverse relationship between dependent and independent variable and indeed follows the findings by Ighodaro and Okiakhi and Devarajan et al. [43]. The results suggest that capital expenditure exerts negative impact on growth due to increasing government expenditure on the sector. However, with government expenditure on areas such military rather than on economic activities will impact negatively on the economic growth of Nigeria. Surprisingly, variance decomposition suggests that recurrent and capital expenditure collectively contribute to change in economic growth.

The study provides empirical assessment of contribution of the public sector expenditure on economic growth. From the result, the long run negative relationship between recurrent, capital expenditure and economic growth holds some policy implication to policy makers and researchers. Controlling the high dependence of economic growth on non-oil revenue and gross fixed capital formation will directly improve the standard of living in the country and indeed enhance efficiency in distribution resources among competing needs. To achieve this objective, public funds must be channeled in rightful projects at the right time to meet the country's demand rather than spending on enormous projects that will not translate into meaningful growth of the economy. The government should direct its expenditure towards the productive sectors like education as it would reduce the cost of doing business as well as raise the standard living of poor ones in the country. The Government should increase its expenditure on rural roads and electricity as this will accelerate the productive sectors as well as raise the standard of living of poor citizens in Nigeria. Such strategy could lead to optimum resource utilization and indeed improve the standard of living in the country.

\section{References}

1. Okemini EB, Uranta DT (2008) Poverty and Criminality in the Niger-Delta Region: A critical analysis. Integrated Social and Management Journal 1: 1-8.

2. Omoke P (2009) Government Expenditure and National Income: A Causality Test for Nigeria. European Journal of Economics and Political Studies 2: 1-11.

3. Oni LB, Aniakam O, Akinsanya TA (2014) Joint effects of capital and recurrent expenditure in Nigeria's economic growth. European Journal of Globalization and Department Research 9: 529-543.

4. Anyanwu JC (1993) Monetary Economics: Theory, Policy and Institutions Hybrid Publishers, Nigeria.

5. Anyanwu JC (1997) Nigerian Public Finance. Agrilakshmi Narain Educational Publishers Itd, Delhi.

6. Jhingan ML (2004) Money, Banking, International Trade and Public Finance (8thedn) Vrinda publishers, Delhi, India.

7. Mankiw NG, David R, David W (1992) A Contribution to the Empirics of Economic Growth. Quarterly Journal of Economics 107: 407-437.

8. Abu N, Abudullahi U (2010) Government Expenditure and Economic Growth in Nigeria, 1970-2008: A Disaggregated Analysis. Business and Economics Journal 4: 237-330.

9. Ebiringa OT, Charlse- ANB (2012) Impact of Government Sectorial Expenditure on economic growth of Nigeria. International Journal of Economic Research 3: 82-92.

10. Bhatia LH (2008) Public Finance, New Delhi Vikas Publishing House, India.

11. Okoro AS (2013) Government Spending and Economic Growth in Nigeria (19802011). Global Journal of Management and Business Research Economics and Commerce 5: 20-30.

12. Chude NP, Chude DI (2013) Impact of Government Expenditure on Economic Growth in Nigeria. International Journal of Business and Management Review 1: 64-71.

13. Ajide BK (2014) Determinants of Economic growth in Nigeria. CBN Journal of Applied Statistics 5: 147-170.

14. Salawu RO (2005) Essentials of Public Finance, Obafeini Awolowo University Press LTD, Nigeria.

15. Keynes JM (1936) General Theory of Employment, Interest and Money, London: Palgrave Macmillian, UK.

16. Wagner A (1893) The foundation of the Political Okonomie, (3rdedn), Leipzig, Germany.

17. Peacock AT, Wiseman J (1961) The Growth of Public Expenditure in the United Kingdom. Princeton: Princeton University Press, UK. 
Citation: Iheanacho E (2016) The Contribution of Government Expenditure on Economic Growth of Nigeria Disaggregated Approach. Int J Econ Manag Sci 5: 369. doi: 10.4172/2162-6359.1000369

Page 8 of 8

18. Solow R (1956) A Contribution to the Theory of economic growth. Quarterly Journal of Economics 70: 65-94.

19. Solow R (1957) Technical Change and Aggregate production function. Review of Economics and Statistics 39: 748-62.

20. Dar A, Amir KS (2002) Government Size, Factor accumulation and Economic growth: Evidence from OECD countries. Journal of Policy Modeling 24: 679692.

21. Barro RJ (1990) Government Spending in a Simple Model of Endogenous Growth, The Journal of Political Economy 5: 103-125.

22. Barro R, Martin I (1992) Public Finance in Models of Economic Growth. Review of Economic Studies 3: 645-661.

23. Roux A (1994) Defense, Human Capital and Economic Development in South Africa. African Defense review no. 19.

24. Glomm JJ, Ravikumar DJ (1997) The growth of Public Expenditure in selected developing nations: Six Carribbean countries. Journal of Public Finance/ Finances Publique 3: 57-74.

25. Pearce DW (1998) The Dictionary of Modern Economics London and Basingstore. Macinillan Press Etd. UK.

26. Afolabi L (1999) Monetary Economics, Revised Ed. Heinemann Educational Books (Nigeria) Pic. Afred, S.E \& Jan, K. (2005). An Essay on Post-Keynesian Theory: A New Paradigm Economics. Journal of Economic Literature 1: 10-32.

27. Nweke J (2004) Capitalist Alternative to Resource Management in Nigeria. Nigeria Journal of Management and Social Sciences: Ebonyi State University, Abakaliki 1: 183-187.

28. Alexander AMO (1990) Public Expenditure and Economic Growth: The Case of Developing nation. Journal of Sustainable Development 2: 56-101.

29. Josaphat PK, Oliver M (2000) Government Spending and Economic Growth in Tanzania (1965-1996). CREDIT Research paper.

30. Ram R (1986) Government Size and Economic Growth: A New Framework and Some evidence from Cross-Section and Time-Series Data. American Economic Review 76: 191-203.
31. Liu C, Hsu C, Younis MZ (2008) The Association between Expenditure and growth: The Granger causality test of the US data. 1974-2002. Journal of Public Budgeting, Accounting and Financial Management 20: 439-452.

32. Fajingbesi AA, Odusola AF (1999) Public Expenditure and Growth. A Paper Presented at a Training Programme on Fiscal Policv Planning Management in Nigeria, Organized by NCEMA, Ibadan, Oyo State, 137-179.

33. Ogiogio G (1995) Government Expenditure and Economic Growth in Nigeria Journal of Economic Management 2: 77-92.

34. Ighodaro CAU, Okiakhi DE (2010) Does the Relationship Between Government Expenditure and Economic Growth Follow Wagner's Law in Nigeria? Annals of University of 'Petrosani Economics 2: 185-198.

35. Rivera-BFL (2004) Democracy, Governance and Economic Growth: Theory and Evidence. Working Paper, Colombia University.

36. N'Zue FF (2011) Economic Freedom and Performance in ECOWAS Countries: A Dynamic Panel Data Approach. Africa Journal of Economic Policy 18:28-53.

37. Wooldridge JM (2010) Introductory Econometrics, (4thedn) Thomson SouthWestern, USA

38. Hosking JRM (2006) On the Characterization of Distributions by their L-moments. Journal of Statistical Planning and Inference 136: 193-198.

39. Athukorala PP, Wasantha A (2003) The impact of foreign direct investment for economic growth a case study of Sri Lanka, 9th International Conference on Sri Lanka Studies, Matra, Sri Lanka.

40. Akinlo AE (2004) Foreign Direct Investment and Growth in Nigeria. Journal of Policy Modelling 26: 627-639.

41. Ibrahim MA (2013) Foreign Direct Investment on Economic Growth in Nigeria (1970-2011). An unpublished Research Project, Fountain University, Osogbo. Osun State, Nigeria.

42. Lutkepohl H (2007) New Introduction to, Multiple Time Series Analysis, Springer, Germany.

43. Deverajan S, Swaroop V, Zou (1996) The Composition of Public Expenditure and Economic Growth. Journal of Monetary Economics 37: 313-344. 